\title{
Maxillary Sinus Cancer pTis TNM Finding v6 and v7
}

National Cancer Institute

\section{Source}

National Cancer Institute. Maxillary Sinus Cancer pT is TNM Finding v6 and v7. NCI

Thesaurus. Code C64755.

Maxillary sinus cancer with a finding of carcinoma in situ. (from AJCC 6th and 7th Eds.) 